\title{
The effects of Moringa stenopetala on blood parameters and histopathology of liver and kidney in mice
}

\author{
Desta Ghebreselassie $^{1}$, Yalemtsehay Mekonnen ${ }^{2}$, Girmai Gebru ${ }^{3}$, Wondwossen Ergete ${ }^{4}$, Kahsay Huruy ${ }^{5}$
}

\begin{abstract}
Background: Moringa stenopetala and related species are commonly used in folk medicine for various human diseases such as antimalarial, antihypertensive, antidiabetic and as antispasmodic.

Objective: The aim of the study is to evaluate the effects of aqueous extract of $M$. stenopetala on blood parameters, and histopathology of liver and kidney in experimental mice.

Methods: Fresh leaves of M. stenopetala were collected from Arbaminch area, Southwest Ethiopia, in November 2005. The leaves were dried and extracted with water. Three month-old Swiss albino male mice, which were kept under uniform laboratory conditions, were randomly divided into four groups (one group of controls and three experimental). (The control group was orally given $0.5 \mathrm{ml}$ of distilled water, and groups II, III and IV were given the aqueous leaf extract of $M$. stenopetala using intragastric tube to achieve the required doses of 600,750 and $900 \mathrm{mg} / \mathrm{kg}$ body weight, respectively once a day at 24 hours intervals for six weeks and then sacrificed). Blood sample was collected from each mouse and examined for hematological and biochemical parameters. Liver and kidney were removed, stained and examined for histopathological profiles. The effects of treatment with aqueous extract of $M$. stenopetala on hematological, biochemical and histopathology features were compared with control group following standard procedures.
\end{abstract}

Results: Mice treated with $900 \mathrm{mg} / \mathrm{kg}$ of the extract per $\mathrm{kg}$ of body weight showed a significant increase in body weight compared to the controls $(\mathrm{P}=0.014)$. Neither a significant change in the weight nor in histopathology of liver and kidney were observed in the animals treated with aqueous extract of $M$. stenopetala compared to those of the controls. Serum glucose level $(P=0.034)$ and serum cholesterol level $(P=0.016)$ decreased significantly after six weeks treatment.

Conclusion: The aqueous leaf extract of $M$. stenopetala is shown to increase body weight and reduce serum glucose and cholesterol level in mice. This indicates nutritional and medicinal values, but we cannot yet recommend its therapeutic use before more and complete studies are done. [Ethiop J Health Dev. 2011;25(1):51-57]

\begin{abstract}
Introduction
Moringa stenopetala, a smooth barked deciduous tropical plant, is a traditional medicinal and nutritional plant in Ethiopia (1). It is widely distributed in the southwestern part of Ethiopia at an altitude range of about 1100 to 1600 meters. The major growing areas are Arbaminch, Negelle and Wellayta Sodo. M. stenopetala is commonly called Shiferaw in Amharic (2). M. stenopetala and related species ( $M$. oleifera) are commonly used in folk medicines as antimalarial, antihypertensive, against stomach pain, antidiabetic, anticholesterol, antispasmodic and to expel retained placentae during birth $(1-6)$.
\end{abstract}

The active constituents in the leaves of $M$. stenopetala and related species such as $M$. oleifera (Behen) are glucosinolates; e.g., 4-(alpha -L-rhamnosyloxy) benzyl glucosinolate which yield 4-(alpha-L-rhamnosyloxy) benzyl isocyanate following enzymatic degradation with myrosinase. Phenol carboxylic acids and fatty acids including oleic acid (60 to $70 \%$ ), palmitic acid (3-12\%) stearic acid (3-12\%) as well as eicosanoic acid and lignoceric acid in addition to mustard oil are other constituents. The antimicrobial effect of $M$. stenopetala leaves and of related species is related to the secondary metabolite constituents $(7,8)$.

Documentation on the use of $M$. stenopetala in the southern regions of Ethiopia has shown that the leaves of Shiferaw are cooked and eaten, for example, with the traditional kurkufa (cereal preparation from maize and sorghum). The people of Konso and the surrounding communities in southern Ethiopia rely on the plant both as food and to treat various ailments $(2,9)$. Fresh leaf extracts of $M$. stenopetatla showed some oxytocic-like activity on guinea-pig ileum and mouse uteri (1). To date, the effect of $M$. stenopetala aqueous leaf extract on blood parameters and on the histopathology of liver and kidney have not been studied. Therefore, the aim of the present study is to evaluate the effects of $M$. stenopetala on some

\footnotetext{
${ }^{1}$ Department of Human Anatomy, College of Health Sciences, Mekele University, E-mail dgw42@,case.edu, (destaghebreselassie@gmail.com), Tel. 251911171882, P. O. Box 1871, Mekele, Ethiopia;

${ }^{2}$ Department of Biology, Faculty of Science, Addis Ababa University, P. O. Box 1176, Addis Ababa, Ethiopia.

${ }^{3}$ Department of Human Anatomy, Medical Faculty, Addis Ababa University, P. O. Box 9086, Addis Ababa, Ethiopia;

${ }^{4}$ Departement of Pathology, Medical Faculty, Addis Ababa University, P. O. Box 9086, Addis Ababa, Ethiopia;

${ }^{5}$ Department of Medical Laboratory Technology, College of Medicine and Health Sciences, University of Gondar, P.

O. Box 196, Gondar, Ethiopia
} 
blood parameters, and histopathology of liver and kidney in laboratory-bred mice.

\section{Methods}

The study was conducted in the Department of Anatomy, Faculty of Medicine and Aklilu Lemma Institute of Pathobiology (ALIPB), Addis Ababa University (AAU).

\section{Plant Material Collection and Preparation}

Fresh leaves of $M$. stenopetala were collected from Arba Minch area, about $500 \mathrm{~km}$ south of Addis Ababa, Ethiopia, in November 2005. Plant sample was identified by the National Herbarium of Addis Ababa University The leaves were cleaned from any extraneous materials, dried at room temperature and ground to powder. The powder was mixed with water in Erlenmeyer flasks and placed in an orbital shaker at room temperature for 24 hours. The mixture was then filtered with cotton and Whatman filter paper $(15.0 \mathrm{~cm}$ size $)$. The filtrates were freeze-dried in a lyophilizer to yield a crude extract. From $388 \mathrm{~g}$ dry leaf, which was dissolved in a total of $1940 \mathrm{ml}$ of distilled water, $40 \mathrm{~g}(10.31 \%)$ of crude extract was obtained. The crude extract was kept in a refrigerator at $-20^{\circ} \mathrm{C}$ until used.

\section{Experimental Animals and Treatment}

Twenty adult (3 months old) Swiss albino male mice weighing 25-27 $\mathrm{g}$ were used. They were bred in the animal house of ALIPB, Addis Ababa University by placing one male to two female mice in a cage. They were kept under uniform laboratory conditions and exposed to $12 \mathrm{hrs}$ of light and $12 \mathrm{hrs}$ of darkness. The animals were provided with free access to pellets and allowed to drink tap water ad libitum throughout the duration of the experiment. The mice were randomly divided into four groups with each group consisting of five mice. Group I served as a control and each mouse was orally administered with $0.5 \mathrm{ml}$ of distilled water. Groups II, III and IV were given the extract to attain the required doses of 600,750 and $900 \mathrm{mg} / \mathrm{kg}$ body weight respectively, once a day at 24 hours intervals for six weeks. The standard WHO procedure for evaluation of herbal medicine for toxicity studies was adopted (10). The doses were selected based on the results of preliminary experiments. The extract was administered with intragastric tube according to the animal's body weight. The animal's weight was recorded at the beginning and end of the experiment.

\section{Hematological and Biochemical Analysis}

With light ether anesthesia, blood samples $(2.0-3.5 \mathrm{ml})$ were withdrawn by cardiac puncture. Hematological analysis for white blood cell count, red blood cell count, platelet count, hematocrit, hemoglobin, mean corpuscular volume, mean corpuscular hemoglobin, and mean corpuscular hemoglobin concentration and lymphocytes was made using a hematology analyser (Sysmex KX-21N Auto Hematology Analyzer, KOBE, JAPAN). Glucose, urea, uric acid, cholesterol, triglycerides and creatinine were measured using an autohumalyser (Autohumalyser $900 S^{\text {plus }}$ Human, Germany). Sodium, potassium, and chloride ions were determined by an electrolyte analyzer (9180 Electrolyte Analyzer, Roche, Germany). Total protein was analyzed by refractometry (Refractometery, American Optical Company, U.S.A).

\section{Liver and Kidney Weights}

Immediately after the blood withdrawal the mice were sacrificed and dissected. Liver and kidney were removed and weighed on a microbalance sensitive to $0.001 \mathrm{mg}$ (Precisa 125A, Switzerland) and recorded. Data were expressed per $100 \mathrm{~g}$ body weight.

\section{Light Microscopic Preparation}

For light microscopic preparation, the whole of the right kidney and the lower one centimeter long part of the right lobe of the liver in coronal and transverse pieces, respectively, were dissected, fixed in $10 \%$ formalin for 24 hours, dehydrated in a graded ethanol series, cleared in xylene, infiltrated and embedded in paraffin. Thin sections $(5 \mu \mathrm{m})$ were cut using a microtome (Leica RM 2125, Leica Microsystems Nussloch GmbH, Germany) and stained with hematoxylin and eosin. The preparation was examined under light microscope (Leitz, Wetzlar, Germany). Photomicrographs of selected samples of the liver and kidney tissue were then taken with TMX 200 film under $\mathrm{x} 10, \mathrm{x} 25$ and $\mathrm{x} 40$ objective using a Leitz Dialux 20 Wild Photo Automat MPS 51. Following the evaluation of the control animals, the liver and kidney tissue in the remaining groups were evaluated blind to treatment.

\section{Statistical Analysis}

All the values in the test are presented as mean and standard error of the mean (mean \pm SEM). Statistical differences between the means of various groups were evaluated by one-way analysis of variance (ANOVA) followed by Student's t-test using SPSS version 13 program. P-values $<0.05$ were considered significant.

\section{Results}

Mice treated with $900 \mathrm{mg}$ of the extract per $\mathrm{kg}$ of body weight showed significant increase in their body weight compared to the controls $(\mathrm{P}=0.014)$. However, there was no significant change in the body weight of mice treated with doses of 600 and $750 \mathrm{mg} / \mathrm{kg}$ when compared to the control groups. No significant change in the weight of liver and kidney was observed in the entire group (Table1).

There was no significant difference in the hematological composition of the blood parameters between the control group treated with $600 \mathrm{mg} / \mathrm{kg}, 750 \mathrm{mg} / \mathrm{kg}$ and $900 \mathrm{mg} / \mathrm{kg}$ $(\mathrm{P}>0.05)$ (Table2). As shown in Table 3, glucose $(\mathrm{P}=0.034)$ and cholesterol $(\mathrm{P}=0.016)$ decreased significantly after treatment with $600 \mathrm{mg} / \mathrm{kg}, 750 \mathrm{mg} / \mathrm{kg}$ and $900 \mathrm{mg} / \mathrm{kg} \mathrm{M}$. stenopetala compared to that of the control group. 
The effects of Moringa stenopetala on blood parameters and histopathology of liver and kidney in mice 53

Table 1: Body and organ weights of mice after treatment with $\boldsymbol{M}$. stenopetala extract

\begin{tabular}{llllcc}
\hline & & & \multicolumn{2}{c}{$\begin{array}{c}\text { Relative organ weight } \\
(\mathrm{g} / 100 \mathrm{~g} \text { bw) }\end{array}$} \\
\hline Group & Treatment (mg/kg/bw) & Initial body weight $(\mathrm{g})$ & Final body weight $(\mathrm{g})$ & Liver & Kidney \\
\hline I & Control (dis. water) & $26.38 \pm 0.69$ & $28.64 \pm 1.95$ & $4.12 \pm 0.10$ & $0.71 \pm 0.23$ \\
II & 600 & $26.46 \pm 0.52$ & $32.44 \pm 1.05$ & $4.24 \pm 0.35$ & $0.74 \pm 0.34$ \\
III & 750 & $27.14 \pm 0.72$ & $33.88 \pm 2.79$ & $4.26 \pm 0.32$ & $0.77 \pm 0.35$ \\
IV & 900 & $26.46 \pm 0.72$ & $40.90 \pm 2.97^{*}$ & $4.34 \pm 0.42$ & $0.79 \pm 0.41$ \\
\hline
\end{tabular}

Values are mean \pm SEM. 'P<0.05, $N=5$ /group

Keys: SEM, standard error of the mean; g, gram; bw, body weight; mg, milligram; kg, kilogram; diss., distilled

Table 2: Hematological analysis of mice after treatment with $M$. stenopetala extract

\begin{tabular}{lcccc}
\hline & & \multicolumn{3}{c}{ Treatment groups $(\mathrm{mg} / \mathrm{kg} \mathrm{bw})$} \\
\cline { 3 - 5 } Hematological parameters & Control (diss. water) & 600 & 750 & 900 \\
\hline WBC $\times 10^{3} / \mu \mathrm{l}$ & $4.40 \pm 0.21$ & $5.10 \pm 0.23$ & $5.10 \pm 0.71$ & $5.66 \pm 0.53$ \\
RBC $\times 10^{6} / \mu \mathrm{l}$ & $7.91 \pm 0.92$ & $8.52 \pm 0.49$ & $8.09 \pm 0.52$ & $8.55 \pm 0.28$ \\
Platelets $\times 10^{3} / \mu \mathrm{l}$ & $396.75 \pm 27.02$ & $397.05 \pm 12.05$ & $389.07 \pm 120.05$ & $399.06 \pm 112.67$ \\
HCT $(\%)$ & $48.22 \pm 1.58$ & $48.62 \pm 1.41$ & $48.44 \pm 1.96$ & $48.04 \pm 1.25$ \\
HGB $(\mathrm{g} / \mathrm{dl})$ & $10.70 \pm 1.00$ & $10.62 \pm 0.93$ & $10.50 \pm 0.60$ & $10.80 \pm 0.32$ \\
MCV (fl) & $84.10 \pm 1.47$ & $82.56 \pm 0.88$ & $82.42 \pm 0.51$ & $85.78 \pm 1.70$ \\
MCH (pg) & $28.24 \pm 0.55$ & $28.20 \pm 0.54$ & $28.80 \pm 0.22$ & $28.70 \pm 0.24$ \\
MCHC (g/dl) & $32.74 \pm 1.42$ & $32.38 \pm 1.10$ & $33.44 \pm 0.48$ & $32.80 \pm 0.39$ \\
Lymphocytes (\%) & $40.74 \pm 3.70$ & $39.74 \pm 2.95$ & $44.66 \pm 3.42$ & $46.18 \pm 2.91$ \\
\hline
\end{tabular}

Values are mean \pm SEM. $\mathrm{P}<0.05, \mathrm{~N}=5$ /group

Keys: WBC, white blood cell count; RBC, red blood cell count; HCT, hematocrit; HGB, hemoglobin; MCV, mean corpuscular volume; $\mathrm{MCH}$, mean corpuscular hemoglobin; $\mathrm{MCHC}$, mean corpuscular hemoglobin concentration.

Table 3: Biochemical analysis of mice after treatment with $M$. stenopetala extract

\begin{tabular}{lcccc}
\hline & & \multicolumn{3}{c}{ Treatment groups $(\mathrm{mg} / \mathrm{kg} \mathrm{bw})$} \\
\cline { 3 - 5 } Biochemical parameters & Control $(\mathrm{DW})$ & 600 & 750 & 900 \\
\hline Glucose $(\mathrm{mg} / \mathrm{dl})$ & $152.30 \pm 47.06$ & $125.40 \pm 12.07^{*}$ & $121.80 \pm 13.46^{*}$ & $135.40 \pm 8.78^{*}$ \\
Urea $(\mathrm{mg} / \mathrm{dl})$ & $52.02 \pm 4.83$ & $47.60 \pm 2.61$ & $49.20 \pm 2.99$ & $49.60 \pm 2.31$ \\
Creatinine $(\mathrm{mg} / \mathrm{dl})$ & $0.78 \pm 5.83$ & $0.80 \pm 5.47$ & $0.80 \pm 0.11$ & $0.80 \pm 5.48$ \\
Total protein $(\mathrm{mg} / \mathrm{dl})$ & $6.80 \pm 0.37$ & $6.52 \pm 0.32$ & $6.72 \pm 0.32$ & $6.70 \pm 0.46$ \\
Uric acid $(\mathrm{mg} / \mathrm{dl})$ & $6.80 \pm 0.37$ & $6.52 \pm 0.32$ & $6.72 \pm 0.32$ & $6.70 \pm 0.46$ \\
Cholesterol $(\mathrm{mg} / \mathrm{dl})$ & $134.60 \pm 15.09$ & $119 \pm 9.10^{*}$ & $118.60 \pm 8.50^{*}$ & $113.20 \pm 5.07^{*}$ \\
Triglycerides $(\mathrm{mg} / \mathrm{dl})$ & $165.80 \pm 26.50$ & $163.40 \pm 16.18$ & $164.20 \pm 40.76$ & $167.40 \pm 39.79$ \\
$\mathrm{Na}^{+}(\mathrm{mmol} / \mathrm{l})$ & $125.80 \pm 5.35$ & $128.80 \pm 5.30$ & $133.00 \pm 4.38$ & $131.20 \pm 5.48$ \\
$\mathrm{~K}^{+}(\mathrm{mmol} / \mathrm{l})$ & $8.30 \pm 0.24$ & $7.36 \pm 0.78$ & $7.36 \pm 0.62$ & $7.48 \pm 0.62$ \\
$\mathrm{Cl}^{-}(\mathrm{mmol} / \mathrm{l})$ & $123.00 \pm 2.41$ & $123.60 \pm 2.91$ & $121.80 \pm 3.07$ & $121.20 \pm 3.93$ \\
\hline
\end{tabular}

Values are mean \pm SEM. * $\mathrm{P}<0.05, \mathrm{~N}=5$ /group, Key: $\mathrm{DW}$, distilled water 
Light microscopic observation with the doses of 600 $\mathrm{mg} / \mathrm{kg}, 750 \mathrm{mg} / \mathrm{kg}$ and $900 \mathrm{mg} / \mathrm{kg}$ of M. stenopetala showed no marked histopathological changes on the livers and kidneys of mice as compared to the control group (Figs. 1 and 2). The liver and kidney histology of the control mice showed characteristic features showing normal central vein lined by endothelial cells, radiating hepatic cells and hepatic sinusoids (Fig. 1A) and Bowman's capsule lined with outer parietal layer (squamous capsular cells) and inner visceral layer (podocyte cells), urinary space, proximal convoluted tubules, distal convoluted tubules, macula densa, vascular pole, respectively (Fig. 2A).
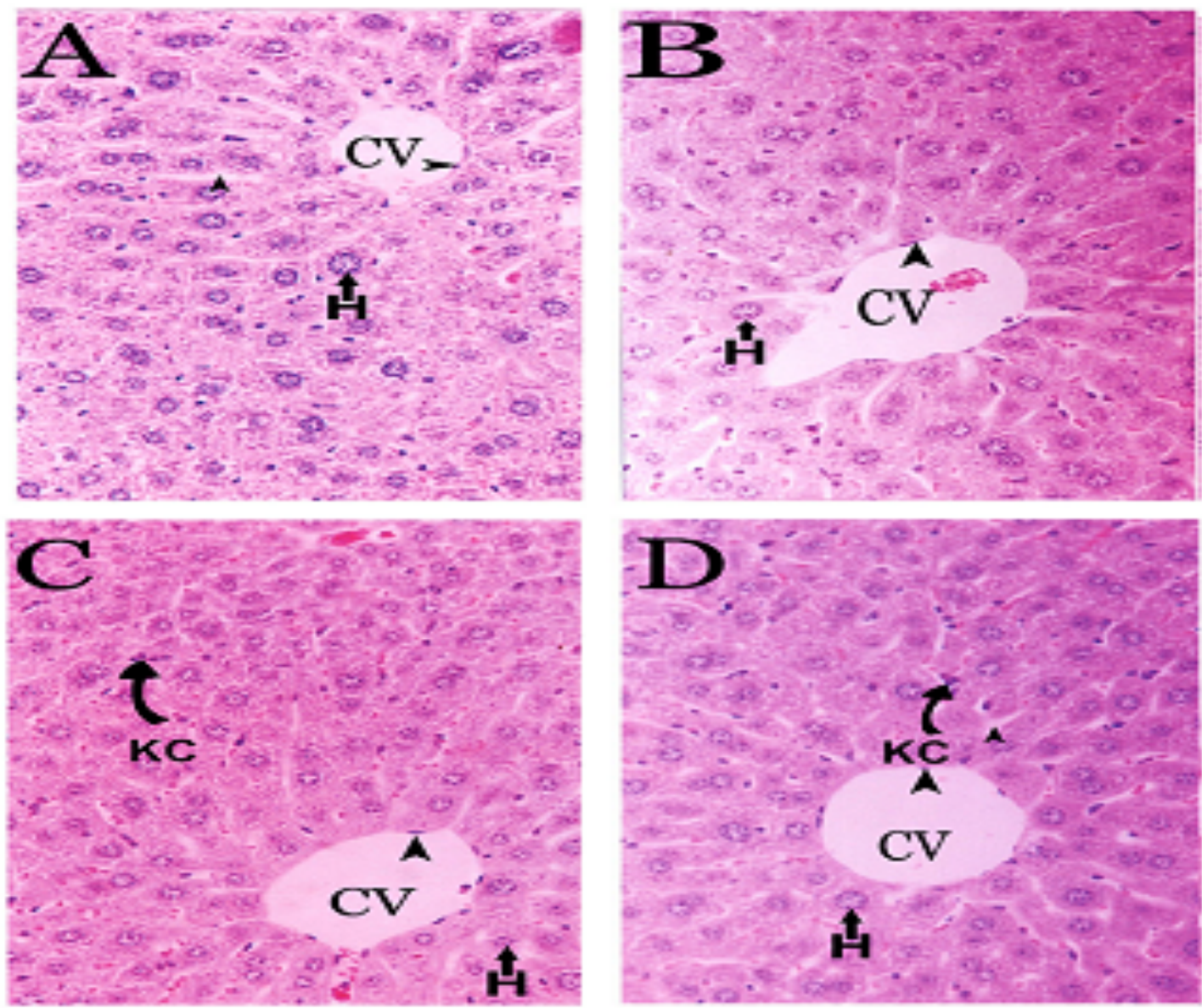

Figure 1: Photomicrographs of liver of untreated (control) mouse liver (A) (H and $E, \times 25)$. (B) Mice treated with $600 \mathrm{mg} / \mathrm{kg}$ bw of $M$. stenopetala leaf extract. (H and E, x25). (C) Mice treated with $750 \mathrm{mg} / \mathrm{kg} \mathrm{bw} \mathrm{of} M$. stenopetala leaf extract. (H and E, x25). (D) Mice treated with $900 \mathrm{mg} / \mathrm{kg} \mathrm{bw}$ of $M$. stenopetala leaf extract (H and $\mathrm{E}, \mathbf{x 2 5 )}$

$\mathrm{CV}=$ Central vein, $\mathrm{H}=$ Hepatocytes, Large arrow head=Endothelial cells, Small arrow head= Sinusoids, $\mathrm{KC}=$ Kupffer cells 

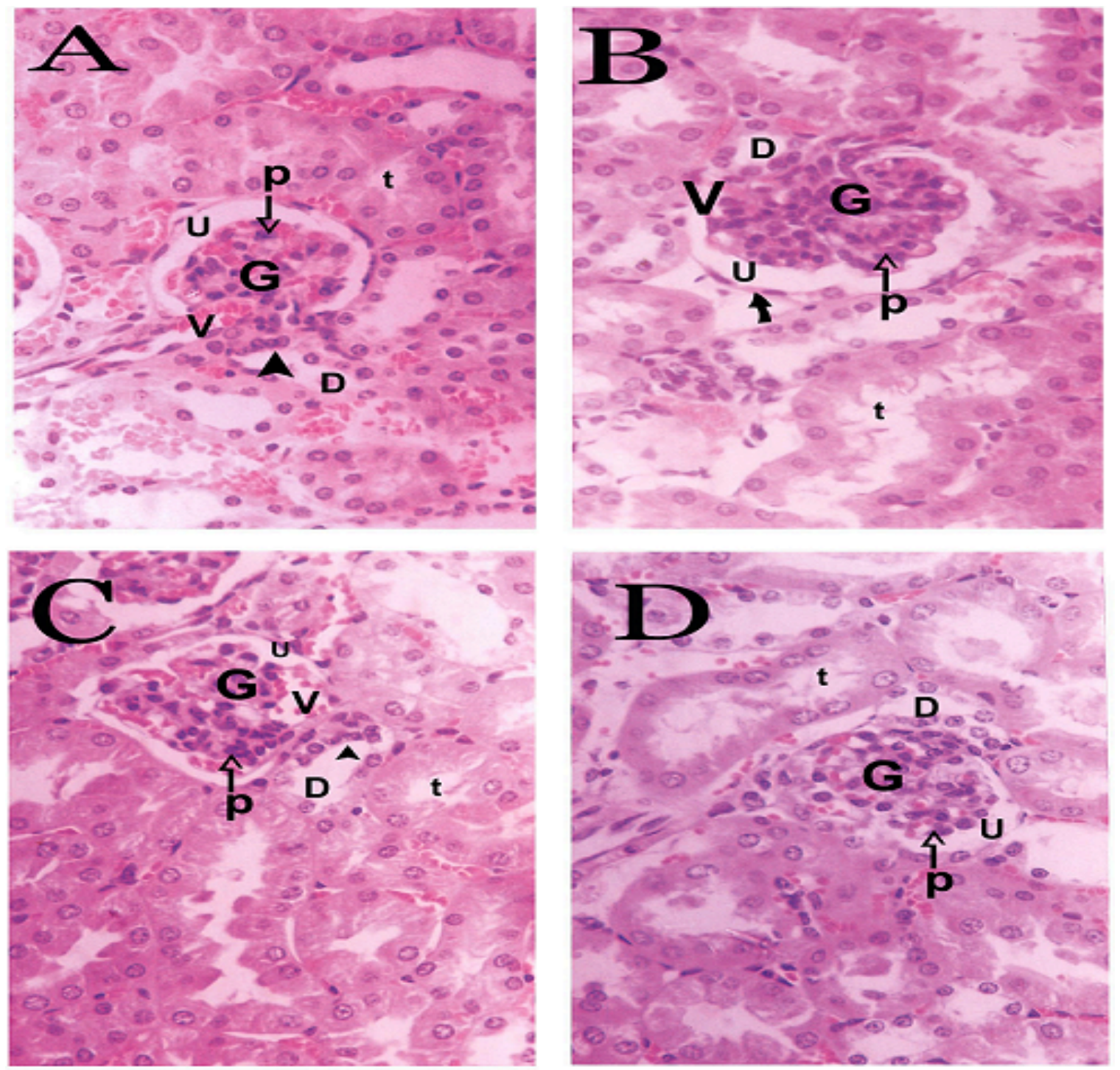

Figure 2: Photomicrographs of kidney of untreated (control) mouse kidney (A) (H and E, x40). (B) Mice treated with $600 \mathrm{mg} / \mathrm{kg}$ bw of $M$. stenopetala leaf (H and E, x40). (C) Mice treated with $750 \mathrm{mg} / \mathrm{kg}$ bw of $M$. stenopetala leaf extract (H and E, x40). (D) Mice treated with $900 \mathrm{mg} / \mathrm{kg}$ bw of $M$. stenopetala leaf extract ( $\mathrm{H}$ and E, x40).

$\mathbf{G}=$ Glomerulus, Curved arrow $=$ Squamous cell, $p=$ Podocytes, $u=$ Urinary space, $t=$ Proximal convoluted tubule, $\mathrm{D}=$ Distal convoluted tubule, arrow head= Macula densa, $\mathrm{V}=$ Vascular pole.

\section{Discussion}

In this study, the effects of long-term treatment with $M$. stenopetala aqueous leaf extract on some hematological and biochemical parameters of the blood, and histopathology of liver and kidney were investigated.

Treatment with different doses of the extract was well tolerated by all the animals, as there were no toxic effects observed by direct visual observation of the animals throughout the experiment. There was no death and apparent behavioral changes recorded during the course of the experiment in all treatment groups as compared to the control group. This might suggest the non-toxic effect of the extract (11). The rate of food and water intake of the mice given 600,750 and $900 \mathrm{mg} / \mathrm{kg}$ doses of $M$. stenopetala aqueous leaf extract was comparable with those of the control group. In previous experiments it was established that M. stenopetala was not toxic even at higher doses; showing why the plant is edible.

Mice treated with a dose of $900 \mathrm{mg} / \mathrm{kg}$ bw of $M$. stenopetala aqueous leaf extract showed statistically significant increase from $26.46 \pm 0.72 \mathrm{~g}$ to $40.90 \pm 2.97 \mathrm{~g}$ in their body weight $(\mathrm{P}=0.014)$. The increase in weight might be due to the fact that $M$. stenopetala is a good source of nutrition. This is in agreement with the previous studies done somewhere else $(12,13)$, who reported that $M$. stenopetala contains important nutrients such as vitamins, proteins, minerals, carbohydrates and fats. It was also reported that calcium is essential at all ages irrespective of physiological status of individuals and for the normal development of skeletal system (14, $15)$. 
There was a slight increase in liver and kidney weight ratio of mice treated with doses of 600, 750 and $900 \mathrm{mg} / \mathrm{kg}$ bw as compared to the control group although it was not statistically significant $(\mathrm{P}>0.05)$. This might be because of the presence of glucosinolate in $M$. stenopetala aqueous leaf extract $(7,16,17)$, as has been described that rats fed with diets containing sixindividual glucosinolates produce small increase in the weights of liver and kidneys.

In this study, blood glucose levels of mice treated with 600,750 and $900 \mathrm{mg} / \mathrm{kg}$ bw M. stenopetala decreased significantly from $152.30+47.06$ to $125.40+12.07$, $121.80 \pm 13.46$ and $135.40 \pm 8.78, \mathrm{mg} / \mathrm{dl}$ respectively $(\mathrm{P}=0.034)$. This is in agreement with the findings of Jaiswal et al. (18), who reported that blood glucose level decreased after administration of $M$. oleifera aqueous leaf extract to rats. This may suggest that $M$. stenopetala may have an insulin-like effect on peripheral tissues either by promoting glucose uptake and metabolism or by inhibiting gluconeogenesis. It is likely that the aqueous extract of the leaves has some effect of increasing the tissue utilization of glucose $(19,20)$ by inhibiting hepatic gluconeogenesis or absorption of glucose into the muscles and adipose tissues (21).

Similarly, mice treated with doses of 600, 750 and 900 $\mathrm{mg} / \mathrm{kg}$ bw of $M$. stenopetala aqueous leaf extract had significantly decreased their blood cholesterol level from $134.60+15.09$ to $119.60+9.10,118.60+8.50$ and $113.20 \pm 5.07$, respectively, in a dose dependant-manner $(\mathrm{P}=0.016)$. This is in agreement with the study reported for Moringa oleifera leaf extract that showed hypocholesterolemic activity $(22,23)$. It was reported that the mechanism of cholesterol reduction is thought to be through the lowering of plasma concentrations of LDL by B-sitosterol, the bioactive phytoconstituent isolated from Moringa oleifera $(22,24,25)$. Therefore bsitosterol or a similar constituent in the leaves of $M$. stenopetala may be responsible for this effect as well. However, the extract did not show significant change $(\mathrm{P}>0.05)$ on urea, creatinine, total protein, uric acid, triglycerides, $\mathrm{Na}^{+}, \mathrm{K}^{+}$and $\mathrm{Cl}^{-}$as compared to the control group. This might be an indication of the non-toxic action of $M$. stenopetala on the body metabolism of the mice.

In addition, mice treated with all the doses of $M$. stenopetala aqueous leaf extract did not show any morphological changes in the liver cells. This is in agreement with the in vitro cytotoxicity study done by Mekonnen et al., (26), who reported that an aqueous extract of leaves from $M$. stenopetala on hepatocytes did not affect cell viability. Furthermore, no significant histopathological changes were observed in the kidneys of the mice treated with all doses. This might be substantiated by the results of biochemical parameters of the blood, such as urea and creatinine which are the main indicators of kidney damage (27-31). Since none of these pathological symptoms were observed in all the mice investigated, $M$. stenopetala leaf extracts might not have adversely affected the kidneys.

In conclusion, this study showed that treatment of mice with the aqueous leaf extract of $M$. stenopetala showed that there was body weight increase in the mice and that there were no after adverse effects observed. From previous work on $M$. stenopetala showing the availability of important nutrients $(12,13)$ and medicinal value $(1,2)$, further studies are warranted to fractionate the active principle and find out the mechanism(s) of action of $M$. stenopetala leaf extract on blood glucose and cholesterol levels in animal models to ascertain its therapeutic importance.

\section{Acknowledgements}

The study was financially supported by a grant from Addis Ababa University (AAU). We would like to thank the animal keeper of ALIPB and the laboratory technicians of the Faculty of Medicine (AAU) and the Tikur Anbassa Hospital in Addis Ababa.

\section{References}

1. Mekonnen Y. Effects of ethanol extract of Moringa stenopetala leaves on guinea-pigs and mouse smooth muscle. Phytotherapy Research 1999; 13: 442-444.

2. Mekonnen Y, Gessesse A. Documentation of the uses of Moringa stenopetala and its possible antileishmanial and anti- fertility effects. SINET. Ethiopian Journal of Sciences 1998; 21: 287 -295.

3. Faizi S, Siddiqui BS, Salam R, Siddiqui S, Aftab K, Gilan, HA. Fully acetylated carbamate and hypotensive thiocarbamate glycosides from Moringa oleifera. Phytochemistry 1994; 38: 957-963.

4. Leuck M, Kunz H. Synthesis of active principles of the leaves of Moringa oleifera using S -pent-4 -ethyl thioglycosides. Carbohydrate Research 1998; 312: 33- 44

5. Tahiliani P, Kar A. Role of Moringa oleifera leaf extract in the regulation of thyroid hormone status in male and female rats. Pharmacological Research 1999; 41:319-323.

6. Kalogo Y, Rosillon F, Hammes F, Verstracte W. Effect of water extract of Moringa oleifera seeds on the hydrolytic microbial species diversity of a UASB reactor treating domestic wastewater. Letters in Applied Microbiology 2000; 31: 259-264.

7. Mekonnen Y, Draeger B. Glucosinolates from Moringa stenopetala. Planta Medica 2003; 69: 380382.

8. Fahey WJ. Moringa oleifera: A review of the medical evidence for its Nutritional, Therapeutic, and Prophylactic Properties, Part 1. Trees for Life Journal 2005; 1-15.

9. Jahn SA. The traditional domestication of the multipurpose tree Moringa stenopetala (Bak.f.) Cuf. in the Ethiopian Rift Valley. Ambio 1991; 20: 244247. 
10. General guidelines for methodologies on research and evaluation of traditional medicine (document WHO/EDM/TRM/2000.1). Geneva: WHO; 2000.

11. Faizi S, Siddiqui BS, Salam, R, Aftab K, Shaheen F, Gilan HA. Hypotensive constituents from the pods of Moringa oleifera. Planta Medica 1998; 64: 225228.

12. Teshome B, Mekonnen Y, Umeta M. Food value of M. stenopetala. 2001; Department of Biology, Addis Ababa University, Ethiopia.

13. Mekonnen Y, Jiru D, Sonder K. Screening of Moringa accessions for nutritive value and palatability. 2007; Proceedings, Ethiopian Institute of Agricultural Research, Addis Ababa, Ethiopia. pp. 383-89.

14. Goodhart RS, Shills ME. Modern nutrition in health and disease: $5^{\text {th }}$ ed. Academic press 1993; New York, Pp. 80-96.

15. Pankaja N, Prakash J. Availability of calcium from kilkeerai (Amaranthus tricolor) and drumstick (Moringa oleifera) greens in weaning rats. Die Nahrung 1994; 38: 199-203.

16. Bennet RN, Mellon FA, Foidel N, Pratt JH, Dupont MS, Perkins L, Kroon PA. Profiling glucosinolates and phenolics in vegetative and reproductive tissues of the multi-purpose trees Moringa oleifera L. and Moringa stenopetala L. Journal of Agriculture and Food Chemistry 2003; 51: 3546-53.

17. Vermorel M, Heaney KR, Fenwick RG. Nutritive value of rapeseed meal: effect of individual glucosinolates. Journal of the Science of Food and Agriculture 2006; 37: 1197-1202.

18. Jaiswal D, Kumar RP, Kumar A, Mehta S, Watal G. Effect of Moringa oleifera Lam. leaves aqueous extract therapy on hyperglycemic rats. Journal of Ethnopharmacology 2009; 123: 392-396.

19. Ali L, Khan AK, Mamun MI, Mosihuzzaman M, Nahar N, Nur-E-Alam M, Rokeya B. Studies on hypoglycemic effects of fruit pulp, seed and whole plant of Momordica charantia on normal and diabetic model rats. Planta Medica 1993; 59: 408412.

20. Gray AM, Abdel-Wahab YH, Flatt PR. The traditional plant treatment. Sabucus nigra (Elder) exhibits insulin like and insulin releasing actions in vitro. Journal of Nutrition 2000; 130: 15-20.
21. Kamanyi A, Djamen D, Nkeh B. Hypoglycemic properties of the aqueous root extracts of Morinda lucida (Rubiaceae) study in the mouse. Phytotherapy Research 1994; 8: 369-371.

22. Ghasi S, Nwobodo E, Ofilis JO. Hypocholesterolemic effects of crude extract of the leafs of Moringa oleifera Lam. in high-fat diet fed Wistar rats, Journal of Ethno- Pharmacology 2000; 69:21-25.

23. Pari L, Kumar NA. Hepatoprotective activity of Moringa oleifera on antitubercular drug-induced liver damage in rats. Journal of Medical Foods 2002; 5: 171-177.

24. Saluja MP, Kapil RS, Popli SP. Studies in medicinal plants part VI. Chemical constituents of Moringa oleifera Lam (hybrid variety) and isolation of 4hydroymellein. Indian Journal of chemistry 1978; 11:1044-1045.

25. Kane JP, Malloy MJ. Treatment of hypercholesterolemia. Medical Clinics of North America 1982; 66: 537-550.

26. Mekonnen N, Houghton P, Timbrell J. The toxicity of extracts of plant parts of $M$. stenopetala in HEPG2 cells in vitro. Phytotherapy Research 2005; 19: 870-875.

27. Mirza M, Yaqeen Z, Khatoon N, Qadri RB. Histopathological studies of some indigenous diuretic medicinal plants in rats. Pakistan Journal of Biological Sciences 2004; 7: 1847-1850.

28. Rostom AH, Makonnen E, Zerihun L, Assefa G. Toxicity study of Jatropha curcas and Ricinus communis seed extracts in the experimental animals. Egyptian Journal of Medical Laboratory Sciences 1998; 7: 93-101.

29. Treasure J. Utrica semen reduces serum creatinine levels. Journal of the American Herbalists Guide 2003; 4: 22-25.

30. Effendy J, Nurtahirah Z, Hussein M. The side effects of Kacip Fatimah extract on liver and kidney of white rats. Journal of Sustainable Science and Management 2006; 1: 40-46.

31. Guyton AC, Hall JE. A text book of medical physiology: $11^{\text {th }}$ ed. Elsevier: Saunders Company, Philadelphia; 2006; pp. 847-848. 